\title{
A Typological Description of Word Order-Rules in Kurdish (Ilami Dialect)
}

\author{
Shahla Sharifi \\ Associate professor in linguistics, Ferdowsi University of Mashhad, Iran \\ E-mail: sh-sharifi@um.ac.ir \\ Amir Karimipour (Corresponding author) \\ MA student in Linguistics, Ferdowsi University of Mashhad, Iran \\ E-mail: am_ka439@stu-mail.um.ac.ir
}

Received: September 21, 2012 Accepted: October 16, 2012 Published: February 28, 2013

doi:10.5296/ijl.v5i1.2434 URL: http://dx.doi.org/10.5296/ijl.v5i1.2434

\begin{abstract}
In this paper, we try to focus on word order variation in the light of the Linearization Hierarchy in Ilami dialect. Several hierarchies have been suggested in this regard. It should be noted that this topic has been discussed in different languages, including English and Persian. We will try to show how Kurdish deal with these so-called "universal hierarchies" and to what extent they are observed in practice. We will see that although Ilami observes some of these rules considerably, asymmetries are also found in this dialect of Kurdish. Nevertheless, mismatches do not necessarily result in producing ungrammatical structures, but only marked ones.
\end{abstract}

Keywords: Typology, Word order, Hierarchy, Kurdish, Markedness 


\section{Introduction}

Typology is a branch of linguistics which studies the structural similarities between languages, regardless of their history, as part of an attempt to establish a satisfactory classification, or typology of languages. Typological comparison is thus distinguished from the historical comparison of languages- the province of Comparative Philology and Historical Linguistics- and its grouping may not coincide with those set up by the historical method (Crystal, 2003). Word order typology, as a main branch of typology, is now considered as one of the most important fields of typological research. Although an awareness of a relationship between the order of verb and object and other word order characteristics dates back to at least the nineteenth century, it is the work of Greenberg (1963) that is generally viewed as marking the beginning of an interest in word order typology. The basic idea of word order typology is that there is an association or correlation between a numbers of word order characteristics, so that given a single word order characteristic of a language, like the order of verb and object, one can predict, at least in a statistical sense, a variety of other characteristics of the language.

word order typology and the notion of markedness are tightly interconnected. In other words, basic word orders are considered as unmarked patterns, based on which unmarked and natural structures are produced. As soon as they violate such hierarchies in any language, they are tagged as "marked structures".

In this article we aim to focalize word order rules in Kurdish. Indeed, we will try to distinguish marked and unmarked structures in different contexts. As far as we know, no prominent work is done to study word order rules in Kurdish or Ilami (as a dialect of Kurdish). So, we decided to study Ilami to show how and which structures are considered as marked or unmarked in this dialect. In order to collect and analyze our data, we got help from one of the authors' linguistic intuition, as a native speaker of Ilami.

Language universals and linguistic typology is a widely studied topic. Hartsuiker et al (1999) hypothesized the existence of a linearization process, which imposes order on a constituent structure. They assume that this structure is specified with respect to hierarchal relations between constituent but not with respect to word order. They tested this hypothesis in a primed picture description experiment. And finally they argue that their results support the notion of a linearization process and reject the alternative explanation that the results should be attributed to persistent selection of a fully specified syntactic frame. Vigliocco \& Nicol (1998) address the question whether hierarchical relations and word order can be separated in sentence production. Based on their experiments they argue that a stage in language production in which a syntactic structure is built prior to a stage in which words are assigned to their linear position. Here we refer to some other typological works: Comrie (1989), Croft (1990)

Downing \& Noonan (1995), Dryer (1997), Greenberg (1974), Greenberg, et al (1978), Horne (1966), Mallison \& Blake (1981), Pullum (1981), Shibatani \& Bynon (1995), Shopen (1985), Song (2000), Vogel \& Comrie (2000), Whaley (1997). 
Present topic has been studied in Persian too. Sharifi (2004) points out some findings about word order rules in contemporary Persian. For example, she claims that Persian tends to be post-field, that is subject preferably comes before other constituents like object, etc. She also rejects full observance of Persian to the above rules (hierarchies), by illustrating some counterexamples. She argues that movements do not necessarily lead to producing ungrammatical sentences; but uttered structures simply seem to be marked and less natural.

\section{An introduction to Kurdish}

Kurdish as a new western Iranian language has speakers dispersed within broad regions of Iran, from west (Kurdistan, Kermanshah and Ilam) to the east (Khurasan), (Gunter: 2004, xxv-xxvi). This language has two main dialect groups. The northern group spoken from Mosul, Iraq, into the Caucasus, is called Kurmānji; in Turkey, Hawar (Turkized Latin) characters are used in the written form (Britannica).

Ilami, a less studied dialect, is one of the Kurdish varieties, and is widely spoken in Ilam, a small mountainous city located in the west of Iran. Ilami shares some features with Kermanshahi and Kalhori, unlike most Kurdish varieties, this dialect has no ergative system. (Kalbassi, 2010)

\section{Theoretical Framework}

Siewierska in his book (1988) proposes seven linearization hierarchies for English. Below, we list and shortly define each hierarchy:

\subsection{The Familiarity Hierarchy}

The notion of 'familiarity' in the sense used here is adapted from Ertel(1997), who defines it in terms of 'closeness to the speaker's cognitive field'. Familiarity is seen to be a relative notion dependent on variables internal to the speaker. It encompasses topicality, givenness, definiteness, referentiality, and perhaps temporal priority, but also purely idiosyncratic factors such as personal preference, emotive involvement, expertise in a given field, etc. ( $p$ 61)

\subsection{The Topic > Comment Hierarchy}

The term 'topic' will be used here in the sense of 'what is spoken of' or 'what the utterance is primarily about'. The term 'comment' will denote what is said about the topic. In most discussions of discourse structure, it is customary to distinguish the part of the utterance that represents the most important or salient piece of information with respect to the pragmatic information between the speaker and addressee; such information will be referred to as the 'focus' (Dik 1978:149). (p, 64-65)

\subsection{The Iconicity Hierarchy (=The Universal Sequencing Conventions)}

The iconicity or experiential inconicity (Enkvist 1981) hierarchy expresses the preference for linearization patterns isomorphic to the temporal order of experiences or actions in the universe of discourse. It is conventional to interpret the linear order in which matters are 


\section{Macrothink}

International Journal of Linguistics

ISSN 1948-5425

2013, Vol. 5, No. 1

presented as representing actual temporal succession. Therefore following examples would normally be understood as depicting different sequences of events.

a. We had a cup of coffee and went for a walk.

b. We went for a walk and had a cup of coffee. $(p, 79)$

\subsection{The Definiteness and Referentiality Hierarchy}

Definiteness and referentiality correlate directly with givenness; definite constituents are assumed to be identifiable by the hearer; referential ones, though not necessarily already identifiable, are taken to exist, and to have a unique identity in the universe of discourse. Therefore the definiteness and referentiality are subsets of the given>new hierarchy.(p, 75)

\subsection{The Person, Semantic Role and Social Status Hierarchy}

\subsubsection{Person}

The order suggested for person is so:

$1^{\text {st }}$ p. $>2^{\text {nd }}$ p. $>3^{\text {rd }}$ p.human $>$ higher animals $>$ other organisms $>$ inorganic matter $>$ abstracts $(p, 49)$

\subsubsection{Semantic Role}

The eligibility of constituents bearing a particular semantic role for subject or object is represented in the following schema:

Subject: agent $>$ patient $>$ recipient $>$ benefactive $>$ instrumental $>$ spatial $>$ temporal

Object: patient $>$ recipient $>$ benefactive $>$ instrumental $>$ spatial $>$ temporal $(\mathrm{p}, 49)$

\subsubsection{Social Status}

Some names which seem to be socially higher are more probable to come first:

Men>women

Boy>girl

\subsection{The Dominant Descriptor Hierarchy}

Studies suggest that the denotata on the left are perceived as more significant or better than those on the right.

Positive >negative

Heavier>lighter

In>out

Host>adjunct

Bigger>smaller $(\mathrm{p}, 60)$ 


\subsection{The Formal Hierarchy}

The investigation of the effect of the formal hierarchies on order will begin with Dik's (1978, 1984) insightful account of this issue captures in his Language Independent Preferred Order of Constituents Schema (LIPOC). LIPOC asserts that, the preferred location of an item to the left of $<$ is before that of an item to the right of $<$.

I. clitic $<$ pronoun $<$ noun phrase $<$ adpositional phrase $<$ subordinate clause $(\mathrm{p}, 31)$

\section{Data Analysis}

Here we represent some Kurdish examples for each hierarchy. In order to explain and clarify the examples more obviously, English literal and exact translations are given for each instance:

Table 1 . The familiarity hierarchy

\begin{tabular}{|c|c|}
\hline Kurdish & English \\
\hline $\begin{array}{l}\text { ælijo xwe } \int k e \text { hatən } \\
\text { maloman } \\
\text { ali and sister his came for house }\end{array}$ & Ali and his sister came to our house. \\
\hline $\begin{array}{l}\text { zenawu bætfele } \quad \text { tJogən ære ter } \\
\text { an } \\
\text { zenaw and children her went for } \\
\text { Tehran }\end{array}$ & $\begin{array}{l}\text { Zenaw and her children went to } \\
\text { Tehran. }\end{array}$ \\
\hline $\begin{array}{l}\text { xwæmu da ləgəm fəræ wærdə jæk qəsæ } \\
\text { myself and mother my a lot with together } \\
\text { spoke } \\
\text { kərdim(ən) }\end{array}$ & $\begin{array}{l}\text { My mother and me spoke together a } \\
\text { lot. }\end{array}$ \\
\hline $\begin{array}{l}\text { daləgu bawgəm fəræ xuwən } \\
\text { mother and father my a lot good are }\end{array}$ & $\begin{array}{l}\text { My parents are very kind and } \\
\text { lovely. }\end{array}$ \\
\hline 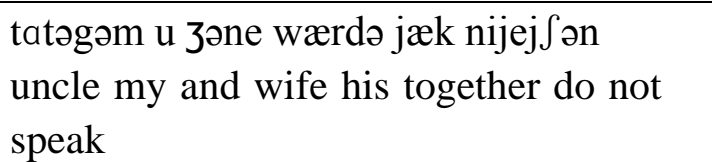 & $\begin{array}{l}\text { My uncle and his wife are not on } \\
\text { speaking terms. }\end{array}$ \\
\hline
\end{tabular}

As we can see some names are likely to come before others and this can be partially the matter of familiarity. In fact nouns which are more familiar and naturally more focal come first. If we look at the first example, we will figure out that"Ali" is more familiar to the speaker/ listener than "his sister", thus it comes first. This general rule can be true about other examples too:

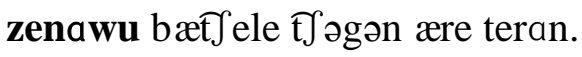

zenaw $>$ bæt $\int \mathrm{el}$

"zenaw" seems to be more familiar to the audience. It should be noted this does not mean "preposing" always makes ungrammatical sentences; however, new sentences may be less 
natural and uncommon:

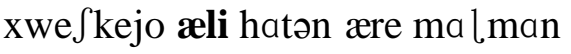

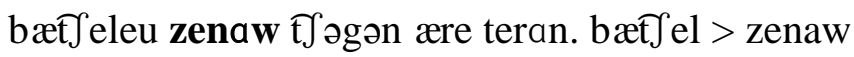

We hinted to "familiarity" as an important factor of determining where a noun should be placed in a sentence. But there are some examples that are difficult to be justified by familiarity criterion alone. In the following example, familiarity can be only one factor determining which noun comes first. Additionally, context and focus seem to be more effective:

daləgu bawgəm fəræ xuwən

New structure is not only grammatical but also as natural as the first:

bawgu daləgəm fəræ xuwən

It seems that in the former mother is focalized and in the latter father, and here familiarity is less consequential.

Table 2. Adjective sequence in kurdish

\begin{tabular}{|l|l|}
\hline Kurdish & English \\
\hline $\begin{array}{l}\text { malə tæmiz u ræjin u gərd u fərd } \\
\text { House clean and beautiful and small and } \\
\text { small }\end{array}$ & A clean small beautiful house \\
\hline $\begin{array}{l}\text { kərə ḑ̧uwan aqəl } \\
\text { boy young wise }\end{array}$ & A young wise boy \\
\hline $\begin{array}{l}\text { ləbas qərməzijə ræjine } \\
\text { cloth red beautiful }\end{array}$ & A red beautiful shirt. \\
\hline $\begin{array}{l}\text { Jamijə Sərinə awdar } \\
\text { watermelon sweet juicy }\end{array}$ & A sweet juicy watermelon \\
\hline
\end{tabular}

In Ilami, it is not common to have a long sequence of adjectives alongside; it tends to use them separately by using conjunctions like " $u$ " (and) after each adjective:

malə tæmiz $\mathbf{u}$ ræjin $\mathbf{u}$ gərd $\mathbf{u}$ fərd

Additionally, order is not very important when adjectives are considered. Indeed, adjectives can come before or after other adjectives to produce grammatical sentences:

Samijə Sərinə awdar

Samijə awdarə Sərin 
Table 3. The topic > comment hierarchy

\begin{tabular}{|c|c|}
\hline Kurdish & English \\
\hline $\begin{array}{l}\text { sæid hade ta ewaræ bejaj } \\
\text { said perhaps till evening come }\end{array}$ & $\begin{array}{l}\text { Perhaps Said came back this } \\
\text { evening }\end{array}$ \\
\hline $\begin{array}{l}\text { daləgəm dæ dæsəm narəhætæ } \\
\text { mother my from hand sad is }\end{array}$ & My mother is annoyed by me. \\
\hline $\begin{array}{l}\text { hadə bətfəm hadə nætJəm } \\
\text { perhaps go I perhaps do not go I }\end{array}$ & I may go. \\
\hline $\begin{array}{l}\text { kolə had3̧ætelæ } \int \text { urtəgæ } \\
\text { all of dishes the wahed }\end{array}$ & She has washed all the dishes. \\
\hline 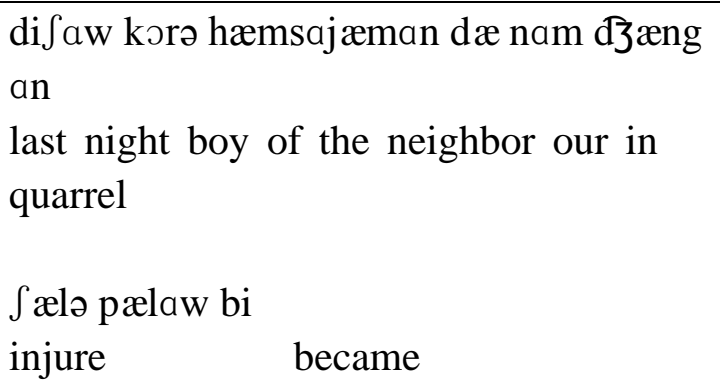 & $\begin{array}{l}\text { Last night, our neighbor's son was } \\
\text { injured in a family quarrel. }\end{array}$ \\
\hline $\begin{array}{l}\text { dængə düjə dəjan nijæ } \\
\text { voice } \quad \text { from them not is }\end{array}$ & I have not heard from them. \\
\hline $\begin{array}{l}\text { su Juwæki Tfəm } \\
\text { tomorrow morning go I }\end{array}$ & I will go tomorrow morning. \\
\hline
\end{tabular}

Topic is an item that is usually known by the speaker/listener and it tends to come at the beginning of sentences as do "sæid" and "da ləgəm" in the following examples:

sæid hade ta ewaræ bejaj

daləgəm dæ dæsəm narəhætæ

It is obvious that these known names containing old information are mentioned first, and then we try to say some new information about them. We refer to this new information as the comment of topic:

sæid hade ta ewaræ bejaj $\rightarrow$ coming of Said

da ləgəm dæ dæsəm narəhætæ $\rightarrow$ annoyance of my mother

Subjects (topics) in the following instances are not overt; however they are still inferable via the verb endings:

kolə hađj̧ætelæ $\int$ urtəgæ $\rightarrow$ Pro ej (She) 
su Juwæki T̃əm $\rightarrow$ Pro mə(I)

We should say that topic in Ilami Kurdish is not necessarily matched with the subject of the sentence, it can take different functions as in the following examples, "kərə hæmsajæman" is the object of a passive verb and "jan" is the object of preposition:

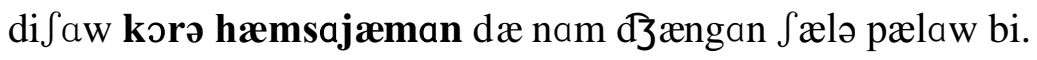

dængə döjə dəjan nijæ

Table 4. The definiteness and referentiality hierarchy

\begin{tabular}{|c|c|}
\hline Kurdish & English \\
\hline $\begin{array}{l}\text { hæsænu kəre wærdə jæk dim } \\
\text { hasan and son his together saw I }\end{array}$ & I saw Hasan and his son together. \\
\hline $\begin{array}{l}\text { saraw nadər wærdə jæk dక̧æng kərdənæ } \\
\text { Sara and Nader together quarrel has done }\end{array}$ & Sara and Nader has had a quarrel. \\
\hline $\begin{array}{l}\text { đӞüd3̧əgu mərxe wærdə jæk sænəm } \\
\text { a chicken and a hen together bought I }\end{array}$ & I bought a chicken and a hen. \\
\hline $\begin{array}{l}\text { aliju bæđ } \int \text { ele hatən ære maləman } \\
\text { Ali and children his came for house } \\
\text { our }\end{array}$ & $\begin{array}{l}\text { Ali and his children came to our } \\
\text { house. }\end{array}$ \\
\hline
\end{tabular}

In Kurdish, definite and referential nouns usually come first. Again it does not mean other forms are ill-formed:

a) hæsæn u kəre wærdə jæk dim

b) kəre ju hæsæn wærdə jæk dim

Although using indefinite words before definite nouns do not make an ungrammatical sentence, the output is rather unnatural. But this is not true about other forms:

a) When two nouns are both definite, order is not important:

saraw nadər wærdə jæk đక̧æng kərdənæ

nadəru sara wærdə jæk đక̧æng kərdənæ

a) When two nouns are both indefinite, order is not important:

đ3̋öđ3̋gu mərxe wærdə jæk sænəm

mərxegu đ3̋öđ3̧əge wærdə jæk sænəm 
Table 5. The iconicity hierarchy

\begin{tabular}{|c|c|}
\hline Kurdish & English \\
\hline 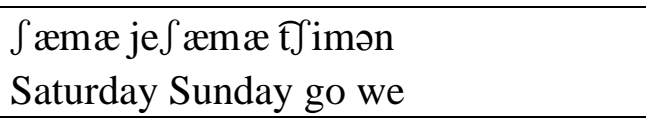 & We will go Saturday or Sunday \\
\hline $\begin{array}{l}\text { saæt TJuwar pænđ3 dijaj } \\
\text { clock four five come she }\end{array}$ & She will come at 4 or 5 o'clock. \\
\hline $\begin{array}{l}\text { hatənu } \mathrm{t} \text { Jəgən } \\
\text { coming and going }\end{array}$ & To come and go \\
\hline $\begin{array}{ll}\text { dæ mal } & \text { ta } \quad \text { danə } \int \mathrm{ga} \\
\text { wæ pa } & \mathrm{t} \int \mathrm{u} \\
\text { from house to university with foot } \\
\text { goes }\end{array}$ & $\begin{array}{l}\text { She walks from the house to the } \\
\text { university }\end{array}$ \\
\hline $\begin{array}{l}\text { dæ } \int \text { uwæki ta ewaræ hamæ daw } \\
\text { from morning to evening run I }\end{array}$ & I work round the clock \\
\hline $\begin{array}{lcc}\text { gjan } & \text { damaw gjan } & \text { sænəmæ } \\
\text { soul } & \text { given have soul gotten have }\end{array}$ & I have been in the agony of death \\
\hline
\end{tabular}

In a sentence, items like numbers, weekdays, time, etc are placed in an ordered manner. For

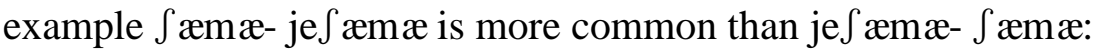

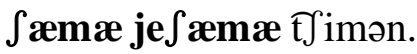

It is also more probable to use the source (place or time) before the goal:

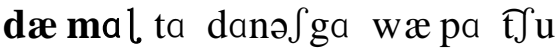

ta danəSga dæ mal, wæ pa t̂u (unnatural)

Table 6. The personal hierarchy

\begin{tabular}{|l|l|}
\hline Kurdish & English \\
\hline $\begin{array}{l}\text { dijækæ ælijo kore dæ bazar dim } \\
\text { yesterday Ali and son his in Bazar saw }\end{array}$ & $\begin{array}{l}\text { Yesterday, I saw Ali and his son in } \\
\text { Bazar. }\end{array}$ \\
\hline $\begin{array}{l}\text { mənu da ləgəm } \\
\text { me and mother my }\end{array}$ & My mother and me \\
\hline $\begin{array}{l}\text { mənu iwæ } \\
\text { me and you }\end{array}$ & You and me \\
\hline $\begin{array}{l}\text { wanu jan } \\
\text { those and these }\end{array}$ & Those and these \\
\hline
\end{tabular}

When "person" is considered, it does not matter which noun/pronoun comes first. In other words we cannot claim that "a" is more acceptable than "b" or "c" than "d", except that the noun/pronoun coming first is probably more focalized: 
a) mənu iwæ

b) iwaw mə

c) mənu da ləgəm

d) daləgəmu mə

Table 7. Semantic role hierarchy

\begin{tabular}{|l|l|}
\hline Kurdish & English \\
\hline $\begin{array}{l}\text { æli ma } \text { Sinæ Surt } \\
\text { Ali car the washes }\end{array}$ & Ali washed the car \\
\hline $\begin{array}{l}\text { həsen kətawæ da döma wæ ræfiqe. } \\
\text { Hesen book the gave back to library }\end{array}$ & $\begin{array}{l}\text { Hesen turned back the book to the } \\
\text { library }\end{array}$ \\
\hline
\end{tabular}

Based on examples, we can claim that agents in Kurdish always come before other semantic roles. But following sentences are still grammatical, albeit less common:

həsen kətawæ da döma wæ ræfiqe. Agent $>\ldots>$ Recipient

kətawæ da döma wæ kətawæxanæ həsen. Recipient> ...> Agent

Table 8. Social status hierarchy

\begin{tabular}{|l|l|}
\hline Kurdish & English \\
\hline $\begin{array}{l}\text { dijætu kore dere } \\
\text { girls and boys has she }\end{array}$ & She has a daughter and a son \\
\hline $\begin{array}{l}\text { 3ənu pejag } \\
\text { woman and man }\end{array}$ & A woman and a man \\
\hline $\begin{array}{l}\text { bawgu kor } \\
\text { father and boy }\end{array}$ & Father and son \\
\hline
\end{tabular}

Social status is not very affective in Kurdish. As we can see "dijæt" and " $3 ə n$ " which are expected to come after kor and pejag, are uttered before:

a) dijætu kore dere

b) bawgu kor

Table 9. The dominant descriptor hierarchy

\begin{tabular}{|l|l|}
\hline Kurdish & English \\
\hline $\begin{array}{l}\text { fæqæt bi } \int \mathrm{a} \text { ja "næ" } \\
\text { only say yes or no }\end{array}$ & Tell me Yes or No. \\
\hline $\begin{array}{l}\text { pöldaru bəpöl } \\
\text { rich and poor }\end{array}$ & Rich and poor \\
\hline
\end{tabular}




\begin{tabular}{|l|l|}
\hline $\begin{array}{l}\text { dærzənu mæf } \text { Needle and thread } \\
\text { gænu xu } \\
\text { bad and good }\end{array}$ & Needle and thread \\
\hline $\begin{array}{l}\text { xasu xəraw } \\
\text { good and evil }\end{array}$ & Good and evil \\
\hline $\begin{array}{l}\text { tængi u xwæ } \int i \\
\text { downs and ups }\end{array}$ & Ups and downs \\
\hline $\begin{array}{l}\text { rasu dəru } \\
\text { truth and lie }\end{array}$ & Truth and lie \\
\hline $\begin{array}{l}\text { tjæl u } \\
\text { bitter and sweet }\end{array}$ & Sweet and bitter \\
\hline
\end{tabular}

If we look at examples mentioned above, we can see that some of them are in accordance with the theory, which states constituents with positive sense come first:

Positive $>$ Negative

a) fæqæt bi $\int$ "a" ja "næ"!

b) xasu xəraw

c) pöldaru bəpöl

d) rasu dəru

and the others are not: Negative $>{ }^{1}$ Positive
a) gænu xu
b) tængi u xwæ $\int \mathrm{i}$
c) tjæl u Jərin

This example is in accordance with the Host>Adjunct relationship:

a) dærzənu mæT̃ $\mathrm{ir}$

Table 10. The formal hierarchy (Noun and pronoun order)

\begin{tabular}{|l|l|}
\hline Kurdish & English \\
\hline $\begin{array}{l}\text { xwegu } \\
\text { herself and husband her }\end{array}$ & She(herself) and her husband \\
\hline $\begin{array}{l}\text { menu bawgəm } \\
\text { I and father my }\end{array}$ & My father and me \\
\hline
\end{tabular}

\footnotetext{
1 . This symbol is conventionally used to show order in an utterance.
} 


\begin{tabular}{lr|l}
\hline $\begin{array}{l}\text { x a luwəmu } \\
\text { jækən } \\
\text { uncle and they }\end{array}$ & bloody each other are & My uncle and they are enemies. \\
\hline
\end{tabular}

If we analyze sentences, to determine whether pronouns or nouns come first, we will recognize that pronouns are more likely to come first, but surely the other form is acceptable (even sometimes more natural as in example 2) yet:

1)

a) xweg u $\int \ddot{0} j ə$

b) Söjə u xwe

2)

a) a. janu xaluwəm xüni jækən

b. xaluwəmu jan xüni jækən

Table 11. The formal hierarchy (Noun Phrase and Prepositional Phrase order)

\begin{tabular}{|l|l|}
\hline Kurdish & English \\
\hline $\begin{array}{l}\text { t } ə \int \text { tə xuwe ærat senəm } \\
\text { something good for you buy I }\end{array}$ & I will buy a surprising gift for you \\
\hline $\begin{array}{l}\text { qəsæ dæ lam nækæ } \\
\text { speak near me do not }\end{array}$ & Do not trust me! \\
\hline $\begin{array}{l}\text { hæ xwæm zanəm } \mathfrak{\text { f } æ ~ w e ~ b i \int ə m ~} \\
\text { only myself know what to say him }\end{array}$ & Only I know what should tell to him \\
\hline
\end{tabular}

Other part of the theory which claims that usually a noun phrase comes before a prepositional phrase $(\mathrm{NP}<\mathrm{PP})$, should relatively be accepted. Following instances show that most often $\mathrm{NP}<\mathrm{PP}$ is true, but reverse is not rejected:

1)

a) a. TfəStə xuwe ærat senəm

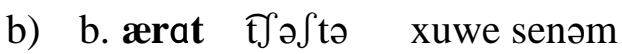

2)

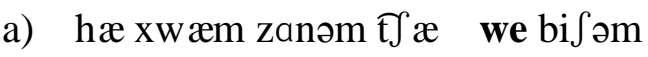

b) hæ xwæm zanəm we $\mathfrak{t} \mathfrak{x}$ bi $\int ə m$

\section{Conclusion}

In this paper, we tried to show, to what extent Kurdish structures, i.e. sentences; phrases, etc are in accordance with the seven hierarchies proposed by Allan (1987) and Siewierska (1988). We saw sentences and phrases which observed the rules. This is why, " $\int \mathfrak{x m \mathfrak { j }} \mathbf{j} \int \mathfrak{x m æ}$

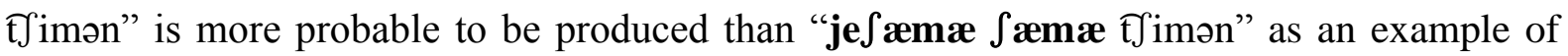


iconicity hierarchy and thus unmarked. On the other hand, many other examples show that Kurdish structures break these rules repeatedly. It can be concluded that Kurdish word order is not that rigid, because it allows movements (at sentence or smaller levels) which can result in producing marked sentences or phrases which seem to be less natural (not necessarily ungrammatical). As we saw "adjective order" is totally flexible. It does not matter which adjective comes first or is nearer to the head (=noun). It is also concluded that the place of an item is not exclusively determined by a single hierarchy. It is more logical to accept that some of mentioned hierarchies are interconnected and consequently affect a sentence/phrase word order together. Thus they should not be considered separately, because they often interact to determine the place in which a constituent can come. If we analyze "ælijo xwe $\int k e$ hatən ære malman" attentively, we will see that it can be a parallel effect of referentiality, familiarity and definiteness on "Ali", coming first.

\section{Reference}

Allan, K. (1987). "Hierarchies and the Choice of Left Conjuncts". Linguistics 23, 51-77. http://dx.doi.org/10.1017/S0022226700011038

Comrie, B. (1989). Langauge Universals and Liguistic Typology: Syntax and Morphology, 2nd edn. Oxford: Blackwell.

Croft, W. (1990). Typology and Universals. Cambridge: Cambridge University press.

Crystal, D. (2003). A dictionary of linguistics \& Phonetics, 5ed, Oxford: Blackwell press.

Downing, P., \& Noonan, P. M (eds.). (1995). Word Order in Discourse. Amsterdam: Benjamins.

Dryer, M. S. (1997). One the Six-way Word Order Typology. Studies in Language, 21, 69103. http://dx.doi.org/10.1075/s1.21.1.04dry

Greenberg, J. H. (1963). Some Universals of Grammar with Particular Reference to the Order of Meaningful Elements. Universals of Language, ed. By Joseph Greenberg, 73-113. Cambridge, MA.

Greenberg, J. H. (1974). Language Typology: A Historical and Analytic Overview. The Hague: Mouton de Gruyter. http://dx.doi.org/10.1515/9783110886436

Greenberg, J. H. et al. (eds.). (1978). Universals of Human Language, 4. Stanford: Stanford University Press.

Gunter, M. (2004). Historical dictionary of the Kurds. Maryland: Scarecrow Press Inc..

Hartsuiker, J. R., Kolk, H. J. H., \& Huiskamp, P. (1999). Priming word order in sentence production. J. Experimental Psychology, (1), 129-147.

Horne, Kibbey M. (1966). Language Typology: 19th and 20th Century Views. Washington, D.C: Georgetown university Press.

Kalbassi, I. (2010). A descriptive dictionary of linguistic varieties in Iran, Institute for 
Humanities and cultural studies, Tehran.

Kurdish Language. (2012). In Encyclopedia Britannica. Retrieved from http://www.britannica.com/EBchecked/topic/325225/Kurdish-language.

Mallison, G., \& Blake, B. (1981). Language Typology: Cross-linguistic Studies in Syntax. Amsterdam: North-Holland.

Payne, D. L. (ed.) (1992). Pragmatics of Word Order Flexibility. Amsterdam: Benjamins.

Plank, F. (1991). "Hypology, typology": The Gabelentz Puzzle. Folia Linguistica, 25, 421-458.

Pullum, G. K. (1981). "Object-initial Languages". International Journal of American Linguistics, 47, 192-214.

Sharifi, Sh. (2004). The Description and Explanation of Word Order in the Contemporary Persian Language from Typological Point of View. (Unpublished $\mathrm{PhD}$ dissertation). Ferdowsi University of Mashhad, Iran.

Shibatani, M., \& Bynon, T. (eds.) (1995). Approaches to Language typology, Oxford: Clarendon.

Shopen, T. (ed.) (1985). Language Typology and Syntactic Description, 3. Cambridge: Cambridge University Press.

Siewierska, A. (1988). Word Order Rules. London: Croom Helm.

Song, J. S. (2000). Linguistic Typology: Morphology and Syntax. Harlow: Pearson Education.

Vigliocco, G., \& Nicole, J. (1998). "Separating hierarchical relations and word order in language production: is proximity concord syntactic or linear?" Cognition, 68, 13-29.

Vogel, P. M., \& Comrie, B. (eds.) (2000). Approaches to the Typology of Word Classes. (EALT, 23.) Berlin: Mouton de Gruyter.

Whaley, L. J. (1997). Introduction to Typology: The Unity and Diversity of Language, Newbury Park Sage. 